\title{
Analisis Penambahan Carboxymethyl Cellulose terhadap Edible Film Pati Umbi Garut sebagai Pengemas Buah Strawberry
}

\section{Analysis of the Addition Carboxymethyl Cellulose to Edible Film Arrowroot Tuber Starch as Strawberry Fruit Packaging}

\author{
Rr.Dewi Artanti Putri' ${ }^{1}$, Desi Sulistyowati ${ }^{2}$, Tias Ardhiani ${ }^{3}$ \\ Program Studi Teknik Kimia, Fakultas Teknik \\ Universitas Negeri Semarang
}

Gedung E1 Lt 2, Kampus Sekaran, Gunungpati, Semarang 50229, Indonesia

Email: 1dewi.artanti.putri@gmail.com, 22desisulist8@gmail.com, ${ }^{3}$ tiasardhiani@gmail.com

\section{DOI:}

10.30595/jrst.v3i2.4911

Histori Artikel:

Diajukan:

24/07/2019

Direvisi:

20/09/2019

Diterima:

25/09/2019

\section{ABSTRAK}

Edible film dari pati merupakan strategi penyusunan kemasan makanan bersifat biodegradable. Film dari pati memiliki kekurangan sebagai kemasan makanan karena realtif mudah robek, sehingga perlu penambahan plasticizer gliserol agar lebih elastis. Sedangkan untuk meningkatkan kuat tarik dan perbaikan struktur permukaan digunakan turunan selulosa yaitu CMC (Carboxy Methyl Cellulose). Umbi garut berpotensial sebagai bahan baku edible film dengan kandungan pati 86,1\%. Dalam penelitian ini dilakukan sintesis edible film dengan penambahan konsentrasi CMC bervariasi (0\%, 5\%, 10\%, 15\%, 20\% b/b). Selanjutnya dilakukan karakterisasi pengaruh konsentrasi CMC pada ketebalan, ketahanan, kelarutan dalam air, kuat tarik, perpanjangan, dan elastisitas. Edible film dengan penambahan 20\% CMC menunjukkan karakteristik ketebalan $(0,144 \mathrm{~mm})$, ketahanan terhadap air $(93,75 \%)$, dan kelarutan dalam air (34\%) terbaik. Edible Film dengan penambahan CMC 10\% menunjukkan karakteristik kuat tarik (3,5597 Mpa) dan elastisitas (25,85 Mpa) terbaik. Nilai perpanjangan terbaik $(18,3 \%)$ dengan penambahan CMC 15\%. Edible film yang telah diaplikasikan pada buah strawberry dapat memperpanjang umur simpan buah hingga 4 hari.

Kata kunci : Edible film, umbi garut, plasticizer, CMC

\begin{abstract}
ABSTRAK
Edible film starch based is a strategy for preparing biodegradable food packaging. Starch-based edible film has a disadvantage as a food packaging because it is torn easily, so it is necessary to add glycerol as plasticizer to make it more elastic. Whereas to increase the tensile strength and repair of the surface structure, cellulose derivatives were used, that is CMC (Carboxy Methyl Cellulose). Arrowroot tubers are potential raw material for edible films with a starch content of $86.1 \%$. In this study, edible film synthesis was carried out with the addition of various CMC concentrations $(0 \%, 5 \%$, $10 \%, 15 \%, 20 \% \mathrm{w} / \mathrm{w})$. Then the characterization of the effect of CMC concentration on thickness, water resistance, solubility in water, tensile strength, elongation, and elasticity was carried out. Edible films with the addition of $20 \%$ CMC showed best characteristics of thickness $(0.144 \mathrm{~mm})$, water resistance (93.75\%), and water solubility (34\%). Edible film with the addition of $10 \%$ CMC shows the best characteristics of tensile strength $(3.5597 \mathrm{Mpa})$ and the elasticity (25.85 Mpa). The best elongation (18.3\%) with the addition of 15\% CMC. Edible films that have been applied to strawberries can extend fruit shelf life up to 4 days.
\end{abstract}

Keywords : Edible film, arrowroot tuber, plasticizer, CMC 


\section{PENDAHULUAN}

Kemasan plastik sintetis atau disebut nonbiodegradable saat ini mendominasi industri makanan Indonesia karena penggunaannya yang fleksibel, multiguna, inovasi beragam, dan ekonomis. Hasil pangan mudah rusak bila tidak ditangani dengan baik terutama pada produk basah seperti buah. Kerusakan dipercepat karena proses oksidasi sehingga perlu proses pengemasan yang bertujuan melindungi makanan, menjaga kualitas dan memperpanjang umur simpan. Pengemas plastik sintetis bersifat toxic karena monomer plastik berimigrasi ke bahan pangan, mudah terurai dalam lemak atau panasdan terakumulasi dalam tubuh (Candra \& Sucita, 2015). Dampak lain yaitu sulit terurai, menimbulkan pencemaran dan kerusakan lingkungan. Sehingga kemasan makanan haruslah bersifat ramah lingkungan.

Alternatif yang digunakan yaitu kemasan ramah lingkungan (biodegradable) seperti edible film. Edible film adalah lapisan tipis dapat dikonsumsi langsung dan ketebalannya kurang dari 0,25 mm, berfungsi menjaga kelembaban, mengontrol pertukaran gas, serta menjaga komponen penting (Embuscado \& C, 2014). Edible film mudah diperbaharui karena senyawa penyusunnya dari tanaman seperti pati dan selulosa. Pati merupakan polisakarida dengan karakteristik fisik mirip plastik, tidak berwarna dan tidak berasa. Salah satu bahan yang berpotensi sebagai bahan edible film adalah pati garut (Maranta arundinaceae L.) dengan kandungan pati sebesar 86,1\% (Yulianti \& Ginting, 2012). Namun kelemahan polisakarida bersifat hidrofilik (mudah mengikat air) sehingga film yang dihasilkan rapuh, permeabilitas uap air tinggi, dan kurang fleksibel. Upaya perbaikan dengan penambahan plasticizer gliserol agar lebih elastis dan mengurangi kekakuan polimer (Waryoko, Raharjo, Wiseso Marseno, \& Karyadi, 2014). Selain itu untuk meningkatkan kuat tarik serta perbaikan struktur permukaan edible film yaitu ditambahkan CMC. Carboxy Methyl Cellulose (CMC) merupakan selulosa eter digunakan sebagai gelasi dengan cara pemanasan dan membentuk film yang sangat baik, hal ini dikarenakan struktur rantai polimer dan memiliki berat molekul cukup tinggi (Putri, Setiawan, \& Anggraini, 2018). Sifat CMC diantaranya yaitu biodegradable, tidak beracun, dan larut dalam air. CMC dapat menunjukkan sifat gelasi berperan sebagai pengental, penstabil, pengikat serta pembentuk tekstur halus dengan tujuan bisa meningkatkan karakteristik mekanis dari edible film (Hidayat, Mantini, \& Sedyawati, 2013). Pada penelitian ini dilakukan sintesis edible film pati garut dengan penambahan pemplastis gliserol serta mempelajari pengaruh penambahan CMC sehingga film yang dihasilkan dapat diaplikasikan sebagai pengemas ramah lingkungan dan ekonomis pada buah strawberry.

\section{METODE}

\subsection{Bahan}

Pada penelitian ini digunakan bahan baku tepung umbi garut yang diperoleh dari pasaran bermerk "Lingkar Organik". Bahan lainnya adalah gliserol yang diperoleh dari PT. Merck Tbk (CAS-No: 56-81-5), CMC (Carboxy Methyl Cellulose), asam sitrat, dan aquades yang diperoleh dari toko bahan kimia Indrasari.

\subsection{Metode}

Pembuatan Pati Umbi Garut

Pembuatan pati garut dilakukan dengan perendaman tepung garut dalam air selama 24 jam menggunakan perbandingan (tepung : air) 1 : 3. Suspensi yang terbentuk disaring, kemudian air hasil penyaringan diendapkan selama 4 jam hingga terbentuk endapan pati. Endapan pati dikeringkan dengan matahari.

\section{Pembuatan Edible Film}

Sintesis edible film mengikuti metode (Ghanbarzadeh, Almasi, \& Entezami, 2010). Pencampuran $5 \mathrm{~g}$ pati dengan $100 \mathrm{ml}$ aquades, gliserol ( $40 \mathrm{ml} / 100 \mathrm{~g}$ pati), dan 0,5 asam sitrat $(10 \% \mathrm{w} / \mathrm{w}$ pati) selama 5 menit. Kemudian suspensi diaduk dengan overhead stirrer (350 rpm) selama 30 menit dalam waterbath pada temperatur $90^{\circ} \mathrm{C}$. CMC $(0,5,10,15$, dan $20 \%$ w/w pati) dilarutkan dalam $75 \mathrm{ml}$ aquades. Suspensi pati dan larutan CMC dicampurkan (75 ml CMC + $100 \mathrm{ml}$ pati, asam sitrat, gliserol) dan diaduk kembali pada temperatur $75^{\circ} \mathrm{C}$ selama 10 menit. Adonan didinginkan hingga temperatur $40^{\circ} \mathrm{C}$ dan aduk perlahan untuk melepaskan gelembung udara. Kemudian dilakukan pencetakan film ratakan hingga mempunyai ketebalan seragam lalu dikeringkan pada temperatur $75^{\circ} \mathrm{C}$ dalam inkubator untuk membentuk lapisan yang stabil.

\subsection{Pengujian}

\section{Ketebalan Edible Film}

Ketebalan film diukur dengan digital caliper bermerk Krisbow ketelitian 0,01 mm pada 5 tempat yang berbeda. Kemudian hasil pengukuran dirata-rata. Menurut ketentuan JIS (Japanesse Industrial Standart) rata-rata 
ketebalan edible film yang baik adalah memiliki ketebalan kurang dari $0,25 \mathrm{~mm}$.

\section{Water Uptake}

Uji ketahanan air pada edible film dilakukan di Laboratorium terpadu Teknik Kimia Unnes dengan cara penimbangan berat awal sampel (Wo). Letakkan sampel film ke dalam wadah berisi aquades. Setelah 30 detik angkat dari wadah, timbang berat film (Wt) yang telah direndam dalam wadah. Rendam kembali film ke wadah tersebut, angkat sampel tiap 30 detik, timbang berat film. Lakukan hal yang sama hingga diperoleh berat akhir film yang konstan. Presentase kadar air berdasarkan persamaan 1 (Ghanbarzadeh et al., 2010):

water uptake $(\%)=\frac{\mathrm{W}_{\mathrm{t}}-\mathrm{W}_{\mathrm{o}}}{\mathrm{W}_{\mathrm{o}}} \times 100$

Solubility

Uji kelarutan air ini mengikuti prosedur dari (Ghanbarzadeh et al., 2010) dilakukan di Laboratorium terpadu Teknik Kimia Unnes. Film disimpan dalam desikator berisi kalsium sulfat kering hingga berat konstan. Kemudian $500 \mathrm{mg}$ film direndam dalam $50 \mathrm{ml}$ aquades pada suhu ruang selama 24 jam dengan agitasi secara berkala. Ambil film dan tempatkan dalam desikator hingga berat konstan untuk mendapatkan berat kering akhir film. Presentase kelarutan dalam air dihitung berdasarkan persamaan 2:

$\% T S M=\frac{\mathrm{Wo}-\mathrm{Wt}}{\mathrm{Wo}} \times 100 \%$

\section{Tensile Strength (Kuat Tarik)}

Pengujian tensile strength dilakukan di Lab Terpadu Universitas Diponegoro . Uji kuat tarik adalah ukuran kekuatan (tarikan) maksimum yang bisa ditahan suatu benda ketika ditarik sebelum fil putus atau sobek. Nilai tersebut didapat bersadar persamaan 3 :

$$
\text { Tensile strength }\left(\mathrm{N} / \mathrm{m}^{2}\right)=\frac{\text { Gaya }}{\text { Satuan luas } \mathrm{m}^{2}}
$$

Elongasi (Perpanjangan)

Perpanjangan merupakan persen pertambahan panjang film maksimum saat memperoleh gaya tarik hingga film putus dibanding dengan panjang awalnya. Nilai tersebut didapat berdasarkan persamaan 4:

$$
\text { Elongasi }(\%)=\frac{\text { Perpanjangan film }}{\text { Pajang awal film }} \times 100 \%
$$

Elastisitas

Kelenturan (elastisity) merupakan hasil dari kuat tarik dibagi perpanjangan. Kelenturan tersebut adalah rasio antara tensile strength dan elongation yang mana jika diregangkan akan kembali pada bentuk yang semula.

\section{HASIL DAN PEMBAHASAN}

\subsection{Pengaruh Konsentrasi CMC Terhadap Ketebalan Edible Film}

Ketebalan merupakan sifat fisik berfungsi sebagai penahan uap air dari produk ke lingkungan maupun sebaliknya (Zuwanna, Fitriani, \& Meilina, 2017). Ketebalan berpengaruh terhadap kuat tarik dan laju transmisi uap air pada film. Pengukuran dilakukan di lima titik berbeda menggunakan digital caliper dengan ketelitian 0,01 $\mathrm{mm}$. Pengaruh konsentrasi CMC terhadap ketebalan edible film seperti pada Gambar 1.

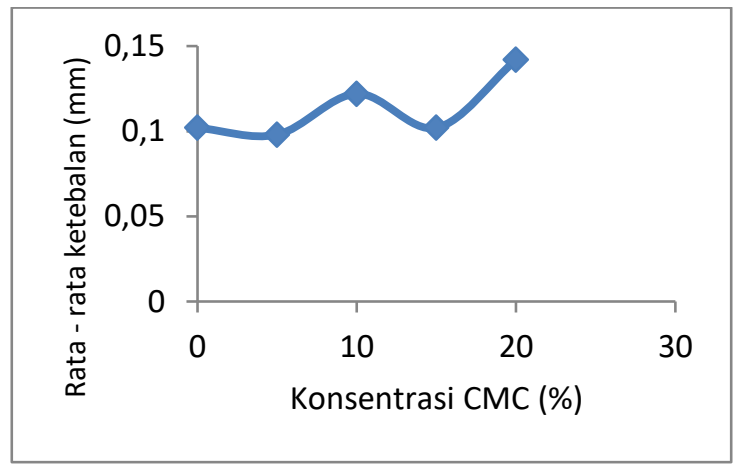

Gambar 1. Pengaruh Konsentrasi CMC

Terhadap Ketebalan Edible Film

Gambar 1 menunjukan konsentrasi CMC (Carboxy Methyl Cellulose) berpengaruh terhadap ketebalan edible film pati garut,semakin tinggi konsentrasi CMC maka ketebalan yang dihasilkan semakin tinggi. Hal ini karena CMC mampu membentuk larutan kompleks untuk meningkatkan viskositas. Selain itu penambahan gliserol juga meningkatkan total padatan dalam larutan sehingga polimer penyusun matriksnya meningkat (Muin, Anggraini, \& Malau, 2017). Data yang dihasilkan sangat fluktuatif, ketebalan tertinggi $0,142 \mathrm{~mm}$ pada konsentrasi CMC 20\% sedangkan ketebalan terendah 0,098 mm pada konsentrasi 5\%. Penurunan ketebalan karena sintesis edible film menggunakan wet process yang memerlukan solven berupa air. Kandungan air pada larutan harus dipisahkan dahulu karena adanya sifat gliserol hidrofilik sehingga dapat mengikat lebih banyak air yang menguap setelah proses pengovenan, hal ini berakibat pada ketebalan film yang tidak merata (Salsabila \& Ulfah, 2017). Edible Film dengan ketebalan 0,098 mm hingga 0,142 mm tergolong memenuhi ketentuan JIS Uapanesse Industrial Standart) karena ketebalan film yang baik yaitu kurang dari 0,25 mm (Zuwanna et al., 2017).

3.2 Pengaruh Konsentrasi CMC Terhadap Water Uptake Edible Film 
Berdasarkan data penelitian maka didapatkan hubungan antara pengaruh konsentrasi CMC terhadap nilai water uptake edible film dari pati umbi garut seperti pada Gambar 2 berikut.

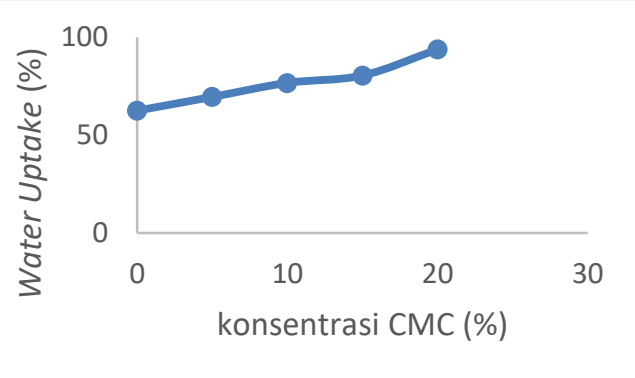

Gambar 2. Pengaruh Konsentrasi CMC

Terhadap Water Uptake Edible Film

Pengaruh penambahan CMC yang semakin tinggi maka semakin tinggi pula nilai water uptake terhadap air. Penambahan CMC menunjukan penyerapan uap air dari film pati sehingga dapat meningkatkan ketahanan air. Hal ini karena pati mampu membentuk ikatan hidrogen dengan gugus hidroksil dan karboksil dari makromolekul CMC dimana struktur yang kuat ini mampu mengurangi difusi molekul air dalam material. Selain itu kombinasi pati dengan serat selulosa pada CMC dapat meningkatkan ketahanan air sebagaimana CMC memiliki sifat hidrofilik (Ghanbarzadeh et al., 2010).

\subsection{Pengaruh Konsentrasi CMC Terhadap Solubility Edible Film}

Kelarutan edible film merupakan faktor penentu kemampuan biodegradasi film sebagai bahan pengemas makanan (Muin et al., 2017). Persen kelarutan merupakan persen berat kering film terlarut setelah perendaman dalam air selama 24 jam. Gambar 3 menunjukan bahwa penambahan CMC (Carboxy Methyl Cellulose) dengan konsentrasi yang berbedabeda mempengaruhi kelarutan film dalam air (solubility).

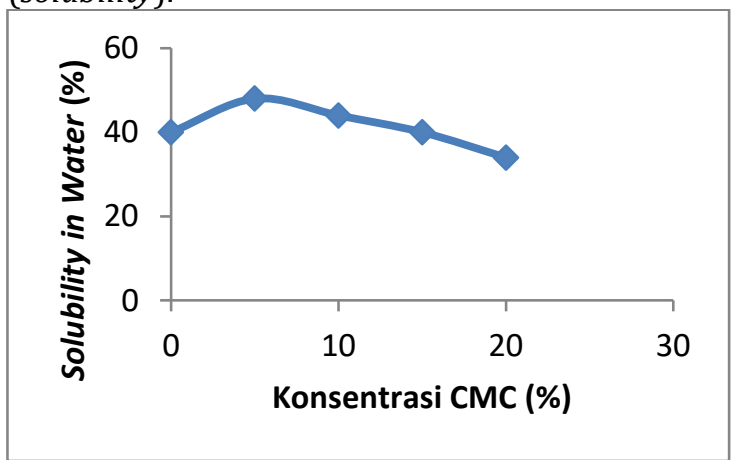

Gambar 3. Pengaruh Konsentrasi CMC Terhadap Solubility Edible Film
Berdasarkan penelitian (Ghanbarzadeh et al., 2010) semakin tinggi konsentrasi CMC maka kelarutan semakin rendah, hal ini selaras dengan penelitian yang dihasilkan. Penurunan daya larut film cenderung berbanding terbalik dengan peningkatan konsentrasi CMC. Hal ini karena padatan terlarut yang berasal dari bahan dasar pembuatan edible film dan meningkatnya jumlah molekul dalam larutan (Rusli, Metusalach, Salengke, \& Tahir, 2017). Nilai kelarutan tertinggi $48 \%$ pada CMC 5\% mengindikasikan film mudah terurai dan digunakan untuk produk siap makan seperti sosis sapi, kelarutan tinggi menunjukkan ketahanan terhadap air lebih rendah namun lebih mudah larut (Fardhyanti \& Julianur, 2015). Sedangkan kelarutan terendah 34\% pada CMC $20 \%$, kelarutan rendah merupakan persyaratan penting untuk pengemas produk pangan basah maupun semi basah seperti buahbuahan (Atef, Rezaei, \& Behrooz, 2014).

\subsection{Pengaruh Konsentrasi CMC Terhadap Tensile Strength Edible Film}

Kuat tarik merupakan kekuatan tarikan maksimum yang dapat dicapai hingga film tetap bertahan sebelum putus (Zuwanna et al., 2017).

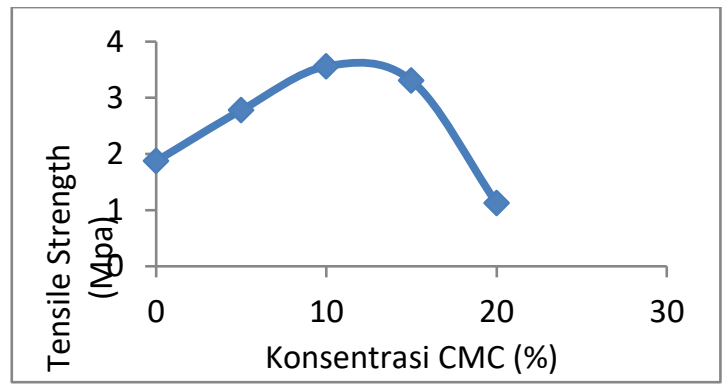

Gambar 4. Pengaruh Konsentrasi CMC

Terhadap Tensile Strength Edible Film

Gambar 4. didapatkan hubungan kuat tarik film dengan variasi konsentrasi CMC menyebutkan adanya kenaikan hingga penambahan 10\% CMC, selanjutnya mengalami penurunan hingga konsentrasi CMC 20\%. Nilai maksimal sebesar 3,5597 MPa pada CMC 10\%, hal ini merupakan kondisi pembentukan film maksimum untuk mencapai nilai tensile strenght tertinggi. Kondisi maksimum menunjukan CMC tepat bereaksi dengan plasticizer sehingga dapat meningkatkan nilai kuat tarik. Semakin tinggi konsentrasi CMC, maka kuat tarik semakin menurun karena karenakan struktur molekul edible film adalah amorf yaitu rantai bercabang tidak tersusun rapat sehingga jarak antar molekul lebih jauh dan kekuatan ikatan molekul menjadi melemah 
akibatnya semakin rendah gaya yang dibutuhkan untuk memutuskan edible film tersebut (Nurindra, Alamsjah, \& Sudarno, 2015). Jika konsentrasi lebih tinggi maka CMC tidak mampu mengikat plasticizer, sehingga film yang dihasilkan keras dan rapuh. Kondisi ini akan menurunkan gaya intermolekuler antar rantai polimer pada CMC dan bahan baku utama yang digunakan (Zuwanna et al., 2017). Nilai kuat tarik terendah sebesar $1,1277 \mathrm{MPa}$ pada CMC 20\%. Namun nilai kuat tarik edible film 1,1277 - 3,5597 sudah dikategorikan sebagai film kemasan makanan karena sudah memenuhi standar kuat tarik edible film menurut JIS (Japanesse Industrial Standart) minimal 0,392266 Mpa (Nurindra et al., 2015).

\subsection{Pengaruh Konsentrasi CMC Terhadap Elongasi Edible Film}

Elongasi adalah perpanjangan saat putus (elongation of break) merupakan presentase perubahan panjang plastik pada saat ditarik sampai putus.

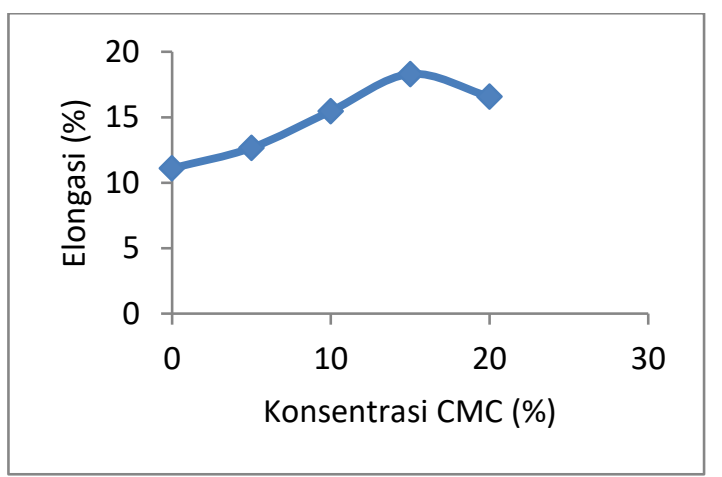

Gambar 5. Pengaruh Konsentrasi CMC

Terhadap Elongasi Edible Film

Berdasarkan Gambar 5 dimana semakin tinggi konsentrasi CMC maka elongasi cenderung meningkat. Persen elongasi terendah sebesar $11,1 \%$ pada film tanpa penambahan CMC menunjukan film mudah rapuh, sehingga penambahan pengental berperan mengatasi kerapuhan yang disebabkan oleh gaya intermolekuler molekul pada bahan baku utaman. Persen elongasi tertinggi $18,3 \%$ pada CMC $15 \%$. Hal tersebut merupakan komposisi campuran dimana dapat meningkatkan kelembaban sehingga menyebabkan film menjadi elastis dan meningkatkan nilai perpanjangannya (Zuwanna et al., 2017). CMC memiliki kandungan gel strength yang tinggi sehingga penggunaan dalam jumlah besar akan menyebabkan kemampuan mengikat air yang lebih baik, hal ini memberikan matriks gel untuk meningkatkan persen pemanjangan dari edible film. Semakin besar nilai pemanjangannya maka semakin baik film tersebut karena lebih elastis dan tidak mudah robek (Nurindra et al., 2015). Hasil perpanjangan menurut JIS Uapanesse Industrial Standart) dimana bahan pengemas makanan yang dikategorikan film adalah mempunyai nilai minimal 70\%. Berdasar data nilai yang dihasilkan belum memenuhi standar sebagai film kemasan makanan (Nurindra et al., 2015). Untuk perbaikan dilakukan penambahan konsentrasi plasticizer karena dinilai mampu mengurangi kerapuhan dan meningkatkan fleksibilitas plastik polimer.

\subsection{Pengaruh Konsentrasi CMC Terhadap Elastisitas Edible Film}

Edible film pati garut memiliki nilai peregangan atau elastisitas yang baik dengan penambahan plasticizer dan diketahui pengaruh penambahan CMC seperti Gambar 6.

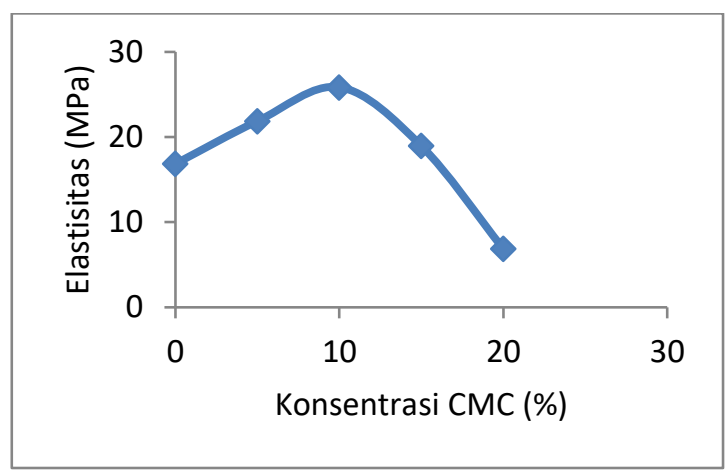

Gambar 6. Pengaruh Konsentrasi CMC Terhadap Elastisitas Edible Film

Semakin tinggi nilai peregangan edible film, semakin baik kekuatannya dalam menahan tekanan atau tarikan sehingga tidak mudah sobek (Yulianti \& Ginting, 2012). Gambar 5. menyebutkan elastisitas maksimal sebesar $28,85 \%$ pada CMC $10 \%$ sedangkan elastisitas terendah pada CMC $20 \%$ sebesar 6,8867. Kenaikan nilai elastisitas hingga penambahan CMC konsentrasi $10 \%$ karena terdapat pengaruh afinitas molekul dalam film. Kemudian mengalami penurunan tajam hingga penambahan CMC 20\% karena tingginya konsentrasi CMC mengakibatkan jumlah polimer penyusun matriks film semakin tebal dan gaya yang dibutuhkan untuk memutuskan spesimen juga semakin besar sehingga nilai kuat tariknya juga semakin besar, hal ini juga menyebabkan film memiliki nilai perpanjangan yang kecil. Nilai elastisitas (modulus young) berbanding lurus dengan kuat tarik (tensile Strength) dan berbanding terbalik dengan perpanjangan (elongasi) (Ariska \& Suyatno, 2015). Edible film dari pati garut dengan penambahan CMC sudah memenuhi Japanesse Industrial Standart minimal elastisitas sebesar 
0,35 Mpa sehingga dapat melindungi dan melapisi produk makanan (Ariska \& Suyatno, 2015).

\subsection{Aplikasi Edible Film Pada Buah Strawberry}

Pengemasan buah strawberry dengan edible film konsentrasi CMC 20\% karena pada kondisi tersebut CMC akan meningkatkan viskositas yang dapat berpengaruh terhadap ketebalan film yang lebih baik (Salsabila \& Ulfah, 2017). Pengaplikasian didasarkan pada perbandingan antara buah strawberry kontrol (tanpa lapisan edible film) dengan buah strawberry dilapisi edible film pada suhu ruang selama 6 hari untuk mengetahui perbedaan laju pembusukannya dan kelayakan film yang dihasilkan sebagai pengemas. Hasil pengamatan didapat buah strawberry dengan lapisan edible film memiliki masa simpan hingga 4 hari dan setelah 4 hari buah tersebut mengalami masa pembusukan ditandai dengan aroma yang tidak sedap. Sedangkan buah strawberry kontrol bermasa simpan hingga 2 hari kemudian mengalami pembusukan dan adanya serangan jamur lebih cepat dibandingkan buah yang dilapisi oleh film. Edible film yang diaplikasikan tidak mempengaruhi aroma, warna dan rasa pada buah.

\section{SIMPULAN}

Penambahan CMC (Carboxy Methyl Cellulose) berpengaruh terhadap sifat mekanik, hidrofobisitas dan karakteristik edible film dari umbi garut. Penambahan konsentrasi CMC dengan konsentrasi yang semakin meningkat maka akan cenderung meningkatkan ketebalan, water uptake serta elongasi. Peningkatan konsentrasi CMC akan menurunkan nilai kelarutan (solubility). Sedangkan untuk nilai kuat tarik dan elastisitas cenderung mengalami kenaikan diawal dan penurunan nilai diakhir. Aplikasi edible film dari umbi garut dengan penambahan CMC sebagai pengemas buah strawberry mampu memperpanjang umur simpan buah hingga 4 hari.

\section{DAFTAR PUSTAKA}

Ariska, R. E., \& Suyatno. (2015). Mekanik Edible Film dari Pati Bonggol Pisang Dan Karagenan Dengan Plasticizer Gliserol The Effect Of Carragenan Concentration On Mechanical And Physical Properties Edible Films From Banana Weevil Starch And Carageenan With Glycerol Plasticizer As
Food. Prosiding Seminar Nasional Kimia, 34.

Atef, M., Rezaei, M., \& Behrooz, R. (2014). Characterization Of Physical, Mechanical,, and Antibacterial Properties of AgarCellulose Bionanocomposite Films Incorporated With Savory Essential Oil. Food Hydrocolloids. https: // doi.org /10.1016/ j.foodhyd.2014.09.037

Candra, R. M., \& Sucita, D. (2015). Sistem Pakar Penentuan Jenis Plastik Berdasarkan Sifat Plastik Terhadap Makanan yang akan Dikemas Menggunakan Metode Certainty Factor (Studi Kasus: CV . Minapack Pekanbaru ). Jurnal CorelT, 1(2), 77-84.

Embuscado, M. E., \& C, H. K. (2014). Structure and Function of Starch-Based Edible Films and Coatings. https: //doi.org/ 10.1007/ 978-0-387-92824-1

Fardhyanti, D. S., \& Julianur, S. S. (2015). Karaktersasi Edible Film Berbahan Dasar Ekstrak Karagenan Dari Rumput laut (Eucheuma Cottonii. Jurnal Bahan Alam Terbarukan, 4 (2), 68-73. https://doi.org/10.15294/jbat.v4i2.4127

Ghanbarzadeh, B., Almasi, H., \& Entezami, A. (2010). Physical properties of edible modi fi ed starch / carboxymethyl cellulose fi Ims. Innovative Food Science and Emerging Technologies, 11(4), 697-702. https://doi.org/10.1016/j.ifset.2010.06.00 1

Hidayat, M. K., Mantini, S., \& Sedyawati, R. (2013). Penggunaan Carboxymethyl Cellulose dan gliserol Pada Pembuatan Plastik Biodegradable Pati Gembili. Indonesian Journal of Chemical Science, 2(2252).

Muin, R., Anggraini, D., \& Malau, F. (2017). Karakterisasi Fisik dan Antimikroba Edible Film dari Tepung Tapioka dengan Penambahan Gliserol dan Kunyit Putih. Jurnal Teknik Kimia, 23(3), 191-198.

Nurindra, A. P., Alamsjah, M. A., \& Sudarno. (2015). Karakterisasi Edible Film Dari Pati Propagul Maangrove Lindur (Bruguiera gymnorrhiza) Dengan Penambahan Carboxymethl Cellulose (CMC) Sebahgai Pemplastis. Jurnal Ilmiah Perikanan Dan Kelautan, 7(2), 125-132.

Putri, D., Setiawan, A., \& Anggraini, P. (2018). Physical Properties of Edible Sorgum Starch Film Added with Carboxymethyl Cellulose. Journal of Physical Science, 
29(2), 185-194.

Rusli, A., Metusalach, Salengke, \& Tahir, M. (2017). Karakterisasi Edible Film Karagenan Dengan Pemplastis Gliserol. JPHPI, 20, 219-229.

Salsabila, A., \& Ulfah, M. (2017). Karakteristik ketebalan edible film berbahan dasar bioselulosa nata de siwalan dengan penambahan gliserol. Jurnal Bioma, 6.

Waryoko, Raharjo, B., Wiseso Marseno, D., \& Karyadi, J. N. W. (2014). Sifat Fisik, Mekanik dan Barrier Edible Film Berbasis Pati Umbi Kimpul (Xanthosoma Sagittifolium) Yang Diinkoprasi Dengan
Kalium Sorbat. Jurnal Agritech, 34(1), 7281.

Yulianti, R., \& Ginting, E. (2012). Perbedaan Karakteristik Fisik Edible Film dari Umbiumbian yang Dibuat dengan Penambahan Plasticizer. Penelitian Pertanian Tanaman Pangan, 31(1990), 131-136.

Zuwanna, I., Fitriani, \& Meilina, H. (2017). Pengemas Makanan Ramah Lingkungan, Berbasis Limbah Cair Tahu (Whey) Sebagai Edible Film. Prosiding Seminar Nasional Pascasarjana, 77-87. 